\title{
Comparison of Target Rates of Return in Latin American Mandatory Pension Systems for the Period 1997-2016
}

\author{
Denise Gómez-Hernández , Felipe Pérez-Sosa \\ Faculty of Accounting and Administration, Autonomous University of Queretaro, Mexico
}

Copyright $\mathrm{C} 2017$ by authors, all rights reserved. Authors agree that this article remains permanently open access under the terms of the Creative Commons Attribution License 4.0 International License

\begin{abstract}
The aim of this work is to analyze which is the required average real return that Latin American workers need to obtain from their retirement funds, in order to get a reasonable pension at retirement, according to each system parameters; and to discuss if those required returns are feasible in the current economical context, or if any changes in the pensions designs are necessary. The results are that from the eight countries under analysis (Chile, Colombia, Costa Rica, Dominican Republic, El Salvador, Mexico, Peru and Uruguay), three do not reach a replacement rate of $70 \%$ or more (Dominican Republic, Mexico and Peru). Hence, in order to increase the replacement rate at an acceptable level in those countries, the actual rate of return on pension assets has to increase as much as 1.6 times, which seems unlikely at the current market conditions. Therefore, the compulsory pension systems of those countries should increase their contribution rate in 2 times from the actual level, with the purpose to provide an appropriate retirement to their members.
\end{abstract}

Keywords Pensions, Retirement, Latin America, Replacement Rate

\section{Introduction}

Estimations from the World Economic Forum indicate that ageing and low returns on pension funds have created a deficit on public pension plans of 400 thousand millions of US Dollars by 2050 [1]. As a result, with the purpose to solve the actuarial and financial unbalances in the Latin American pension systems, and by suggestion of the World Bank [2], many countries from the region shifted their mandatory pension systems from Defined Benefit type (DB) to Defined Contribution type (DC) [3]; and established modifications to the funding processes, the participation of the private initiative in the funds management and some changes in the general parameters of the systems, as the retirement ages and other criteria [4].

This debate of pension reforms has focused on improving the financial sustainability and the administrative efficiency, in response to the consequences of the economic crisis and ageing populations [5]. With the purpose to give a general perspective of the demographic situation in the Latin America countries, the population pyramids are shown in Fig. 1A and 1B [6]. A general situation seen from this figure is that the population in all countries is concentrated at young and middle ages. The pyramid shape has disappeared for all of them, except may be for Dominican Republic. This means, in terms of pensions, that the population at middle ages increased which is going to be the sector that will need a pension in the near future.

Therefore, the Latin American reforms had the main purpose to eliminate the design deficiencies related to the $\mathrm{DB}$, making the pension systems consistent with the demographic context and sustainable for the future generations. Nevertheless, is important to notice that other relevant aspects of Latin American pension systems are the need to widen their coverage and their relevant participation in the development of local financial markets [7]. 


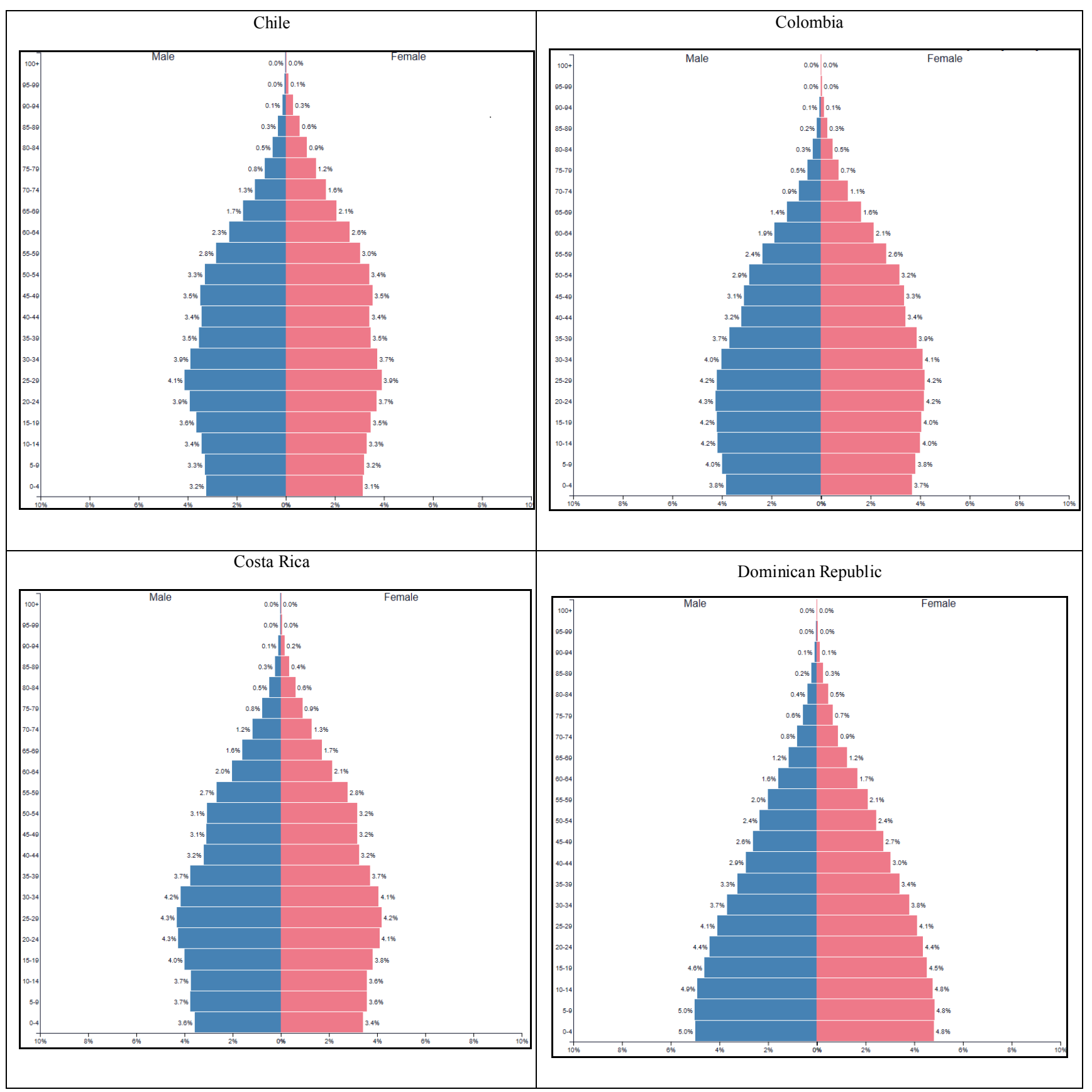

Figure 1A. Population pyramids in Latin America, 2017. 


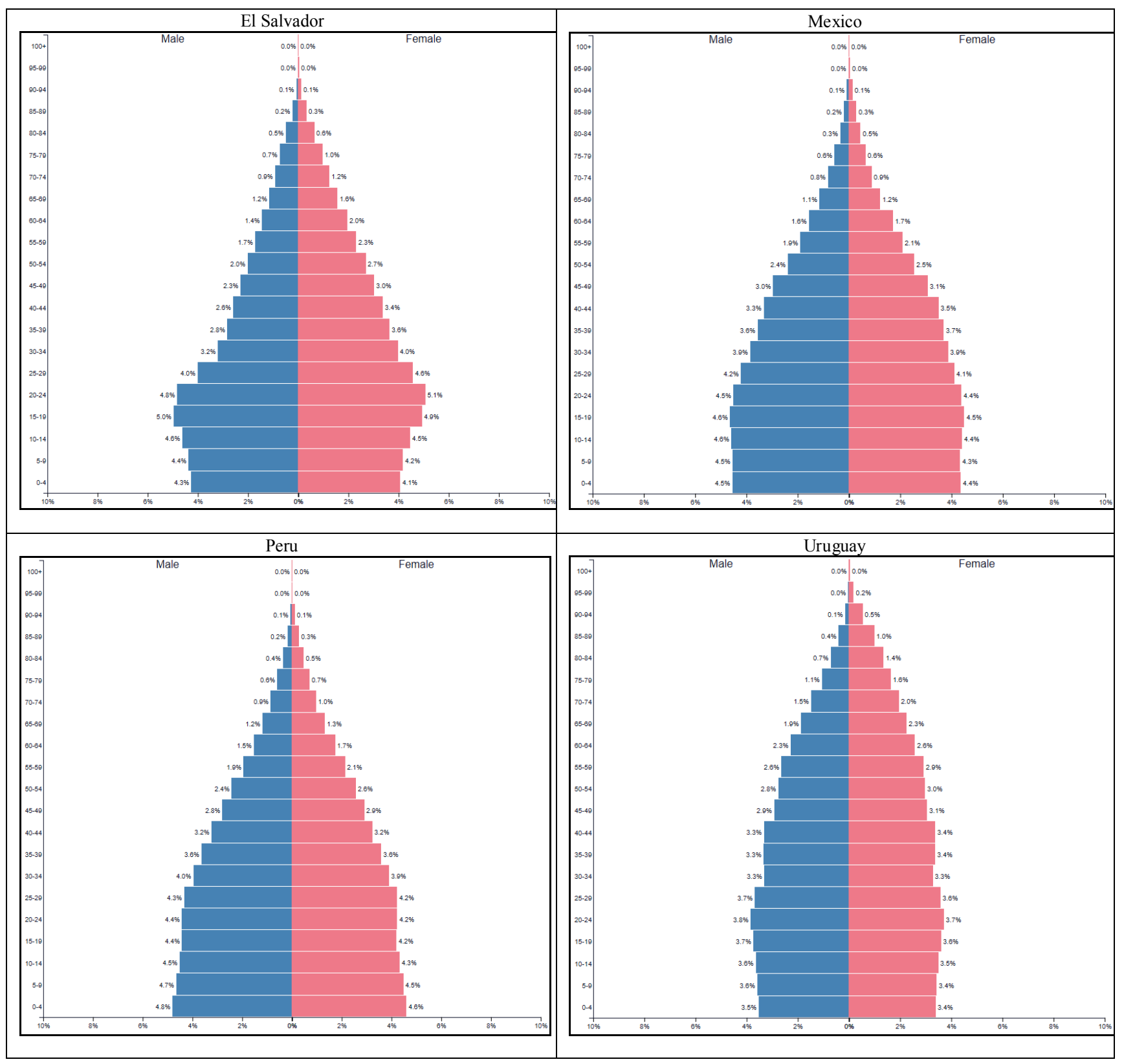

Figure 1B. Population pyramids in Latin America, 2017.

DC plans are often considered the best way to constitute a pension fund, when job mobility is present [8]. Their main characteristic is that they have an established formula to set the contributions to the plan, which usually is a fixed percentage of the worker's income. Another important feature is that these operate with the money value principle, which means that the actual benefits received by the worker at retirement are equivalent to the accrued amount in their pension fund. This guaranties that the worker's savings won't be used to finance the retirement of another one; however, it also implies that there is no certainty about the amount of benefits that the workers receive [9]. Also, in a DC plan the contributions are deposited in an individual account and the total sum of the savings, plus the generated returns, are the available resources to finance the retirement.
It is important to keep in mind that the goal of the worker is not the accumulated sum of his or her account by itself, but the actual income that he will receive as a pension; in relation to the consumption level that will be feasible during retirement [10]. Hence, a key parameter to measure the effectiveness of a determined pension plan is the replacement rate. This indicator represents the percentage of income that will receive the retiree, in comparison with his last salary before retirement.

For workers with average earnings, the gross replacement rate averages $63 \%$ in OECD countries, but there is significant cross-country variation. For instance, in Mexico and the United Kingdom the average replacement rate is less than $30 \%$, while Turkey averages $105 \%$ for average earners [11]. Figure 2 shows the replacement rate for OECD countries [12]. 


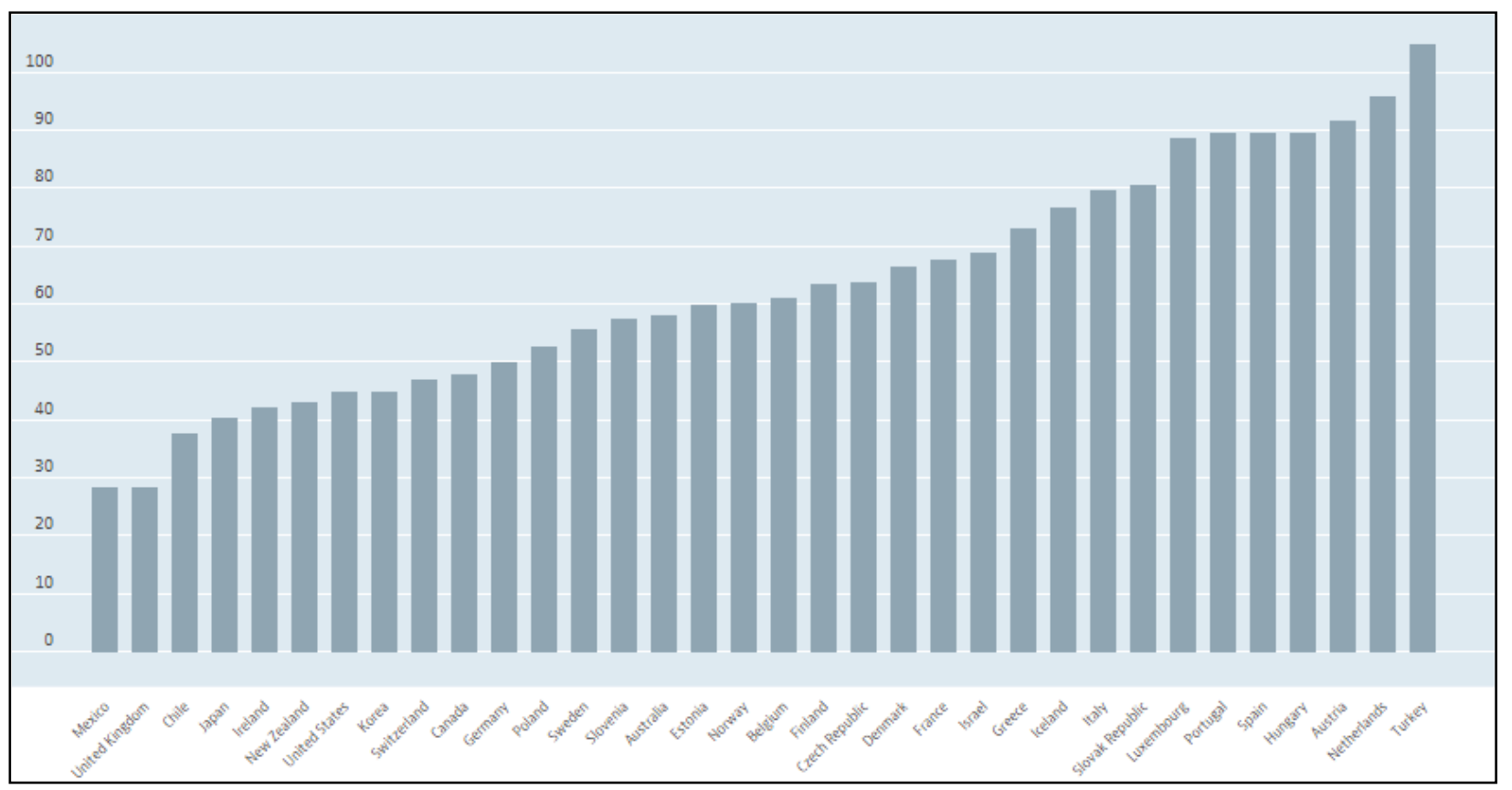

Figure 2. Net pension replacement rates (Men, \% of pre-retirement earnings, 2014)

In this regard, the aim of this work is to analyze which is the required average real return that Latin American mandatory DC pension funds should achieve, in order to provide a reasonable pension at retirement, according to each system parameters; and to discuss if those required returns are feasible in the current economical context, or if any changes in the pensions designs are necessary. In order to do so, the structure of this paper is as follows: In section 2 we review the historical background of the pension reforms in Latin America, with the purpose to examine the general context of the pensions systems within the region; in section 3 we describe our methodology and the outcomes of the research; and finally, in section 4 we discuss our conclusions and implications of the results.

\section{Historical Background}

Since 1981, many Latin American countries have reformed their pensions systems, as a result of economic, social and demographic trends, as well as of the influence of multilateral institutions, such as the World Bank [7]. The first Latin American country to do so was Chile, with the promulgation of the Act of Law number 3,500 in 1980, which was implemented on 1981. This reform introduced the concept of individual accounts, managed by private financial institutions, in which workers save for their retirement during their working life; in opposition to the general account, managed by the government, in which the resources of all working population was allocated before the reform[13].

Following the example of Chile, other Latin American countries shifted their mandatory DB pension plans to DC schemes. Figure 3 [1] geographically shows the Latin American countries that already have adopted the mandatory pension plan DC type, and if those mandatory pension plans are associated to the state or to private companies. In some cases, a DB plan is still in force, coexisting with a DC pension plan. In the case of Chile, where a DC plan exists managed by private institutions, earlier this year announced that an additional $5 \%$ of the worker's salary is going to be managed by a public institution with the purpose to increase the replacement rate and to obtain an insurance with solidary purposes. In the case of Colombia, where a DB/DC system coexists managed by the State, according to the FMI even though the retirement age has been increased for 5 years the public pension system will be solved by 2050 , as the pension deficit is $3.5 \%$ of the GDP. Costa Rica reveled a deficit in pensions for 10 thousand millions of USD which is mainly because of the high benefits given to the judicial employees. In El Salvador, the deficit of 55 million of USD as of 7 of April 2017 was not paid by the government until later that month, by reducing the federal budget on 56 million of USD. In Mexico, a voluntary pension scheme is under design by several institutions, in order to be implemented by enterprises. Earlier this year, Peru increased from $42 \%$ to $44 \%$ the investment of pension funds in foreign assets. Finally, in Dominican Republic the ADAFP (Dominican Association of Pension Fund Managers) recognized the positive impact of the changes in pensions that have been implemented by the government [1].

The regulatory entity and the year of entry to the defined contribution pension system for each Latin America country, included in Figure 2, are summarized in Table 1. 


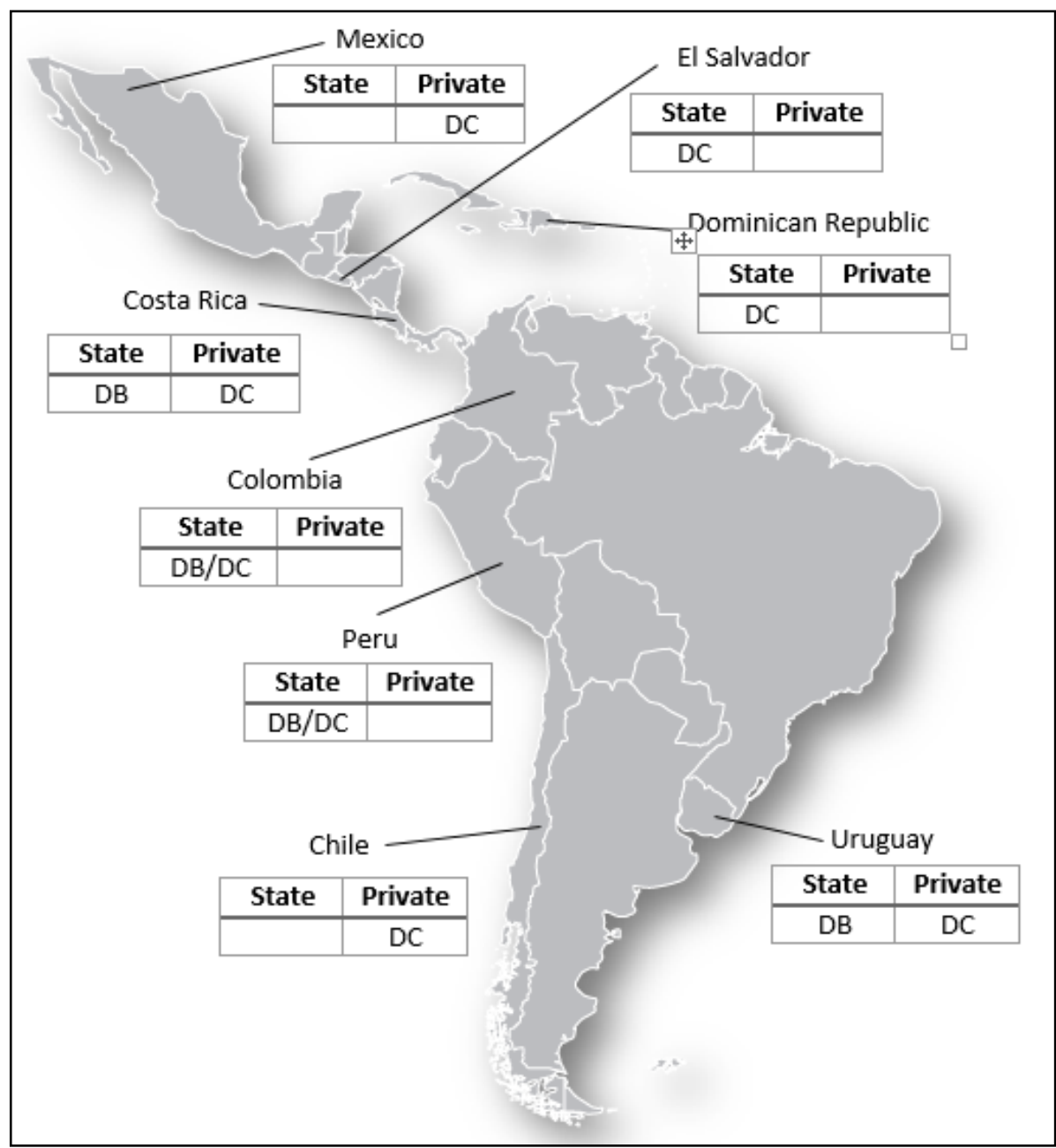

Figure 3. Pension plan type per Latin America country under study

Table 1. DC Scheme entry year and regulatory entity by country

\begin{tabular}{|c|c|c|c|}
\hline Country & Regulatory entity & Regulatory Entity Name & Entry Year \\
\hline Chile & SP & Superintendencia de Pensiones & 1980 \\
\hline Colombia & SFC & Superintendencia Financiera de Colombia & 1993 \\
\hline Costa Rica & SUPEN & Superintendencia de Pensiones & 2000 \\
\hline Dominican Republic & SIPEN & Superintendencia de Pensiones & 2001 \\
\hline El Salvador & SSF & Superintendencia del Sistema Financiero & 1996 \\
\hline Mexico & CONSAR & Comisión Nacional del Sistema de Ahorro para el Retiro & 1997 \\
\hline Peru & SBS Y AFP & Superintendencia de Banca, Seguros y AFP & 1992 \\
\hline Uruguay & BCU & Banco Central del Uruguay & 1995 \\
\hline
\end{tabular}

In some way, the experience of the countries shown in Table 1 can be considered successful from a financial point of view. However, there are many topics still pending, as the coverage enlargement and the improvement of the expected replacement rates which in some cases are estimated to be insufficient to provide a worthy level of life at retirement [8]. For instance, a main challenge of Latin American pensions systems is that, even after the reforms, many workers are excluded from social security, which means that they do not have the benefit of a pension for their retirement [7].

According to the Inter-American Development Bank, OECD and the World Bank, in average, only $45 \%$ of Latin American workers are members of a pension plan. Naturally, this percentage varies depending on the kind of employment. For example, $64 \%$ of the employees with a formal labor relation have a pension fund, but only $17 \%$ of self-employees. Also, the size of the employer counts. In large companies, $71 \%$ of workers are enrolled to a pension scheme, but in small companies only $24 \%$ [14]. In this 
regard, is important to notice that informality is a main obstacle to increase the coverage of Latin American pension systems.

Another pending topic of Latin American pension systems is their incapability to provide an adequate income for retirement to their members. Actually, a great portion of Latin American retirees would need to count on additional income sources, such as active labor, real estate assets and assistance from family and government. As an overview of this situation, in Table 2 are shown the replacement rates for different income levels in the countries under study [14]. It is important to recall that the replacement rate is an indicative of the income that a retiree will earn, as a proportion of his last perceived salary as an active worker.

From Table 1 is straightforward to see that most of the analyzed countries still do not have retirees under their DC system, due the passing time from their reforms. For this reason, is important to forecast the expected replacement rates under the new pension schemes, which may vary from data shown in Table 2, as the general conditions of the pension systems are considerable different.

\section{Data and Methodology}

\subsection{Aim and Purpose}

The aim of this paper is to analyze which is the required average real return that a typical worker from different Latin America countries has to obtain from his fund, in order to get a reasonable pension at retirement age, according to the parameters of each pension system. Also, we discuss if those required returns are feasible in the current economical context, or if any changes in the system parameters are needed in order to achieve acceptable replacement rates. This work is an update and extension of a first published paper in 2014 [15].

According to the purpose of this work, we identify which Latin America countries do not reach replacement rates higher or equals to $70 \%$ and which would be the expected returns of their funds in order to achieve that rate. We used this replacement rate as a benchmark, because it is usually considered adequate for a worthy retirement [16]. However, is important to notice that some research put in context this assumption. Actually, some studies propose that the target replacement rate may be considerable lower than the aforesaid $70 \%$. For instance, a study found that certainly, a median optimal target replacement rate should be of $75 \%$ for married couples and 55\% for singles, but this optimal target varies substantially depending on the life-cycle of each individual. In consequence, the optimal replacement rate for almost half of the population would be below $65 \%$ [17]. In concordance, another study suggests that the optimal replacement rate for the medium earner should be around $40 \%$ of average monthly earnings, based on actual retirement patterns in the United States [18]. As well, there is research that has found that the $70 \%$ target is not correlated with the quality of life, due to many reasons (such as an inadequate measurement period, components of consumption and family size), so a single replacement rate may not be the most appropriate [19]. Nevertheless, for practical reasons and following the generally accepted criteria, we base our analysis on a $70 \%$ replacement rate target. The methodology used is described as follows.

\subsection{Data}

On a first stage, we identify the main characteristics of the pension systems of the countries shown in Table 1 . The data is obtained from 1997 to 2016, which is the most updated data published and is summarized in Tables 3 and 4[20]. From all the Latin America countries that have incorporated the DC pension system (Table 1), only 3 of them presented insufficient data required for the analysis: Bolivia, Nicaragua and Panama. Then, the countries included in this analysis were: Chile, Colombia, Costa Rica, Dominican Republic, El Salvador, Mexico, Peru and Uruguay.

Table 2. Current replacement rates by income level (for women if different).

\begin{tabular}{|c|c|c|c|}
\hline Country & 0.5 & 1.0 & 2.0 \\
\hline Chile & $60.2(50.7)$ & $43.9(34.4)$ & $39.2(26.2)$ \\
\hline Colombia & 102.6 & $70.8(64.1)$ & $70.8(64.1)$ \\
\hline Costa Rica & 87.7 & 79.4 & 79.4 \\
\hline Dominican Republic & 22.8 & 22.8 & 22.8 \\
\hline El Salvador & 93.1 & 46.6 & $29.2(23.3)$ \\
\hline Mexico & 57.3 & $29.5(28.6)$ & $29.4(21.9)$ \\
\hline Peru & 16.8 & 70.6 & $24.9)$ \\
\hline Uruguay & 52.5 & 52.5 & 35.3 \\
\hline
\end{tabular}


In Table 3, the average monthly wage refers to the average salary of persons contributing into pension funds in each country. The contribution to the individual retirement account is presented as a $\%$ of gross wage and it refers to the contribution made only to the individual account as some countries make contributions to other account types such as: to finance administrative fees, death and disability insurance and public programs.

Table 3. Average monthly wage and $\%$ of contribution to the individual retirement account.

\begin{tabular}{|c|c|c|}
\hline Country & $\begin{array}{c}\text { Average monthly } \\
\text { wage (US\$) }\end{array}$ & $\begin{array}{c}\text { Contribution to the } \\
\text { individual retirement } \\
\text { account }\end{array}$ \\
\hline Chile & 1078 & 10.00 \\
\hline Colombia & 473 & 11.50 \\
\hline Costa Rica & 1002 & $4.25(1)$ \\
\hline Dominican Republic & 453 & 8.00 \\
\hline El Salvador & 625 & 10.80 \\
\hline Mexico & 532 & $7.79(2)$ \\
\hline Peru & 904 & 10.00 \\
\hline Uruguay & 1320 & $11.49(3)$ \\
\hline
\end{tabular}

(1) Costa Rica: the total contribution rate of $4.25 \%$ is divided by the employee (1\%) and employer (3.25\%).

(2) México: the total contribution rate of $6.50 \%$ is divided by the employee $(1,125 \%)$, employer $(5,15 \%)$ and government $(0,225)$. The remaining percentage is the called "cuota social".

(3) Uruguay: the total contribution rate to the individual capitalization system is $15 \%$. However, the administration fee and the survival and disability fee were removed.

The total contribution made into the individual account of the employee has remained unchanged since the pension plan system was adopted in Chile and Costa Rica. All other countries, except Uruguay, increased this contribution through the time. Uruguay is the only case that decreased the contribution percentage as it started with $12.34 \%$ [21].
If we compare these values with the average as of 2012, we can see that the average monthly wage in Chile, Colombia and Mexico decreased in the last 4 years. On the other hand; countries such as El Salvador, Peru and Uruguay increased the salary during the same period. The most dramatic scenario is for Colombia, where the average monthly salary decreased almost by half. Costa Rica and Dominican Republic suffered slight changes.

In Table 4[19], the average real rate of return refers to the historical average of the rates of return as of December 2016. The average annual administrative fees refer to the weighted average administrative fees charged by the funds, when charged on flows apply; and to the weighted average administrative fees per assets under management, otherwise. The data from Table 4 shows that Peru and Uruguay charge fees on the two types: on flows and on assets under management. Costa Rica and Mexico charge fees on the second type; while Chile, Colombia, Dominican Republic and El Salvador charge on flows. Then, it is possible to say that Costa Rica provides a lower net average real rate of return than Mexico. This is because the net rate of return in Costa Rica is $4.131 \%$ and in Mexico $5.06 \%$.

The average rate of return of Table 4, increased only for Dominican Republic in the last 4 years. All other countries have decreased this average rate of return on the pension funds. The most dramatic case being Costa Rica, as this value decreased 3.65 percentage points. On the other hand, when looking at the charge fees per country; Chile, Costa Rica and Mexico decreased the fees; whereas, Peru and Uruguay introduce a charge fee on assets under management. Colombia, Dominican Republic and El Salvador remained unchanged. It is worth to mention that Uruguay is the only case that increased the charge on flow and at the same time introduced a new charge fee, in the last 4 years.

Table 4. Average annual real rate of return and administrative fee per country

\begin{tabular}{|c|c|c|c|}
\hline \multirow{2}{*}{ Country } & \multirow{2}{*}{ Average real rate of return } & \multicolumn{2}{|c|}{ Average annual administrative fee } \\
\cline { 3 - 4 } & & Charge on flows & Charge on assets under management \\
\hline Chile & $8.37 \% \mathrm{a})$ & $1.28 \%$ & \\
\hline Colombia & $7.88 \% \mathrm{~b})$ & $3 \% \mathrm{f})$ & $0.699 \%$ \\
\hline Costa Rica & $4.83 \%$ & & \\
\hline Dominican Republic & $4.81 \%$ & $1.50 \%$ & $1.09 \%$ \\
\hline El Salvador & $7.76 \%$ & $2.20 \% \mathrm{~g})$ & $1.21 \%$ \\
\hline Mexico & $6.15 \% \mathrm{c})$ & & $0.00146 \%$ \\
\hline Peru & $7.52 \% \mathrm{~d})$ & $2.48 \%$ & \\
\hline Uruguay & $7.78 \% \mathrm{e})$ & $3.31 \%$ & \\
\hline
\end{tabular}

a) Based on "fondo tipo C (intermedio)" which represents $37 \%$ of the total funds.

b) Based on the historical average of the "Fondo Moderado", which corresponds to the $85.2 \%$ of the total funds.

c) Based on the weighted average rate of return for the funds "Siefore SB1, SB2, SB3, SB4 and SB5".

d) Based on the return on the private pension systems (SPP) calculated by the "Estudios Previsionales de la Asociación de Administradoras privadas de Fondos de Pensiones de Perú".

e) Based on the adjusted returns by the UI (Unidad Indexada). The return presented is of the "Subfondo de Acumulación".

f) According to the law, there is a maximum percentage of the salary of $3 \%$ for the sum of charge on assets under management and the disability and survival insurance premium.

g) According to the law, there is a maximum percentage of the salary of $2.2 \%$ for the sum of charge on assets under management and the disability and survival insurance premium. 
Table 5. Average investment portfolio per country as of December 2015.

\begin{tabular}{|c|c|c|c|c|c|c|c|c|}
\hline \multirow{2}{*}{ Country } & \multirow{2}{*}{ State } & \multicolumn{2}{|c|}{ Corporate } & \multicolumn{2}{c|}{ Financial } & \multicolumn{3}{c|}{ Foreign } \\
\cline { 3 - 10 } & & Fixed income & Equities & Fixed income & Equities & Fixed income & Equities \\
\hline Chile & 22.9 & 6.5 & 8.1 & 17.2 & 0.7 & 13.3 & 30.9 & 0.4 \\
\hline Colombia & 35.3 & 2.0 & 11.1 & 8.3 & 7.0 & 3.0 & 29.7 & 3.6 \\
\hline Costa Rica & 73.3 & 1.2 & 0.0 & 12.6 & 2.2 & 1.9 & 4.6 & 4.4 \\
\hline Dominican Republic & 69.9 & 2.6 & 0.0 & 27.6 & 0.0 & 0.0 & 0.0 & 0.0 \\
\hline El Salvador & 79.4 & 6.9 & 0.0 & 5.4 & 0.0 & 6.9 & 0.0 & 1.4 \\
\hline Mexico & 47.1 & 25.2 & 6.2 & 2.0 & 0.0 & 0.9 & 15.5 & 3.0 \\
\hline Peru & 17.8 & 6.8 & 15.9 & 18.0 & 1.1 & 2.1 & 38.1 & 0.3 \\
\hline Uruguay & 59.4 & 8.9 & 4.4 & 3.7 & 0.0 & 10.0 & 0.0 & 13.7 \\
\hline
\end{tabular}

The average rate of return per country is obtained from the investment portfolio per country. The assets included in these investment portfolios are shown on average in Table 5 [22]. The data shows that El Salvador is the most conservative country as $80 \%$ of their portfolio pension assets are invested in fixed income. The least conservative being Peru is $18 \%$. This, however, is not reflected on the average rates of return which in both countries are high compared with others.

\subsection{Model and Assumptions}

By using the data in Table 3 and 4, the calculation of the accumulated fund at the end of the individual's working life for each of the counties is performed. The value of the fund is obtained for each scenario as shown in (1).

$$
\begin{aligned}
& f_{t}=f_{t-1}(1+i) *(1-a)+\left(C_{t}-C F_{t}\right) *(1+i / 2) * \\
&(1-a / 2)
\end{aligned}
$$

Where:

$$
f_{t}=\text { Accumulated fund until period } t
$$

$i=$ Real rate of return used to project the value of the fund

$a=$ The weighted average charge on assets under management

$C_{t}=$ The value of the contribution at period $t$

$C F_{t}=$ The value of the charge on flows at period $t$

Also, we can define $C_{t}=c * S_{t}$ and $C F_{t}=d * S_{t}$ where $S_{t}$ is the worker's salary at period $t$ and $c$ is the $\%$ of contribution to the fund shown in Table 3 and $d$ the $\%$ of the charge on flows shown in Table 4. Once the accumulated value of the fund is obtained, the replacement rate is calculated as in (2) [23]:

$$
R R=\left(\frac{f_{T}}{\ddot{a}_{65}^{(12)} I_{T}}\right)(1-\delta)
$$

Where $\ddot{a}_{65}^{(12)}$ is the actuarial annuity rate at age 65 payable monthly in advance, $I_{T}$ the base income of the worker at final period $T$ and $\delta$ the charge on the purchase of an annuity made by the insurance company. Also, for comparative purposes the assumptions made to obtain an accumulated value of the fund are as follows:

- An initial value of the fund of 0 .

- 40 years of accumulation period for all the countries ${ }^{1}$.

- An annual increase on salaries of $2 \%$ for all the countries.

- A charge on the purchase of an annuity made by the insurance company equals to 0 .

- An annual rate of $4 \%$ to calculate the value of the annuity.

\subsection{Results}

The results of the replacement rate obtained for each country are shown in Table 6, where is observed that some of the countries under analysis do not reach a minimum replacement rate of $70 \%$. Only Chile, Colombia, El Salvador and Uruguay do. On the contrary, Costa Rica, Dominican Republic, Mexico and Peru do not even reach a replacement rate of $60 \%$. This means that for a worker living in these countries, it is reasonable to expect to retire with a pension of less than $50-60 \%$ of his or her last salary at the end of his or her working life.

Table 6. Replacement rate on a basis of 40 years of accumulation fund

\begin{tabular}{|c|c|}
\hline Country & 40-years Replacement Rate (\%) \\
\hline Chile & 102 \\
\hline Colombia & 88 \\
\hline Costa Rica & 18 \\
\hline Dominican Republic & 33 \\
\hline El Salvador & 87 \\
\hline Mexico & 41 \\
\hline Peru & 52 \\
\hline Uruguay & 83 \\
\hline
\end{tabular}

There is not a common parameter for all countries of

1 Although all the countries have different retirement ages, for comparative purposes a working life of 40 years is assumed for all of them. 
why an average worker reaches lower or higher replacement rates. For example, we could assume that the countries with lower salaries reach lower replacement rates. However, being Dominican Republic and Colombia the countries with considerable lower salaries, only Dominican Republic does reach an extremely low replacement rate. Another assumption that we could make is that countries with charge fees on assets under management reach lower replacement rates; however, only 3 out of 4 countries that charge this type of fees do not reach a minimum replacement rate of $60 \%$. Only Uruguay that does charge fees of this type, reach a replacement rate higher (i.e. $83 \%$ ). A reason for that could be that, if we look at this fee rate, it is extremely low compared with the other three countries.

Another parameter that is worth to mention is the percentage of the salary contributed to the pension fund. Then, as Costa Rica and Dominican Republic have the lowest contribution rates; it can be a parameter to reach low replacement rates. Also, even though Peru has one of the highest contribution rates, a low replacement is reached mainly because it is one of the two countries that charge both fee types.

Also, is important to recall that the accumulated fund depends on the return rates, as can be seen in (1). Therefore, as we used the historical rates of each country as a reference for our projections, this certainly have a direct impact on the results. That is, those countries with higher historical return rates are more likely to achieve acceptable replacement rates, than countries with lower historical return rates. However, this is not always true, the exception being Costa Rica as its replacement rate is considerable lower than Dominican Republic being their historical average returns quite similar. Then, despite our results show that there is a strong relationship between the historical returns and the replacement rate, that is not always true as this is a consequence of several factors acting together to reach a replacement rate at the end of the working life of an individual. These factors are the level of salary, the percentage of the contribution, the average fees and the historical returns.

Comparing these values with the results obtained in the previous study as of December 2014, we can see that the replacement rates decreased in all the countries, except in Dominican Republic; which as of 2014 was $25 \%$ compared with an estimated $33 \%$ in this work. The country that suffered a higher decreased in the replacement rate is Colombia with 46 percentage points, followed by Uruguay with 43 . Mexico is the country that has maintained its replacement rate practically unchanged at low levels.

In order to obtain a $70 \%$ replacement rate in the countries where is not realistic to achieve this goal under the current scenario, a simulation is performed targeting $R R_{t}$ at 0.7 in (2) and obtaining the accumulation rate of return of the worker's fund $i$ in (1). With that, the question that arises is what would be the real rate of return that those pension systems must achieve, in order to provide a pension of $70 \%$ of the salary after 40 years of working life? The results of this analysis are shown in Table 7 and are explained as follows. Given that the historical average rate of return in Costa Rica $4.83 \%$, the investment portfolio for the pension funds is underperforming 5.63 percentage points annually, as it is the difference between the current rate (i.e. 4.83) and the target rate (i.e. 10.5). In the same sense; Dominican Republic is underperforming 2.37, Mexico 1.75 and Peru 1.23. The country that has considerable decreased the average rate of return on pension funds is Costa Rica, as the average as of 2014 was $8.48 \%$ compared with the actual average of $4.83 \%$, as mentioned before.

Table 7. Target rate of return assuming a $70 \%$ replacement rate

\begin{tabular}{|c|c|c|}
\hline Country & $\begin{array}{c}\text { Target real rate of return } \\
\text { for a } 70 \% \text { replacement } \\
\text { rate (\%) }\end{array}$ & $\begin{array}{c}\text { Current average real } \\
\text { rate of return of the } \\
\text { system (\%) }\end{array}$ \\
\hline Costa Rica & 10.5 & 4.83 \\
\hline Dominican Republic & 7.2 & 4.81 \\
\hline Mexico & 7.9 & 6.2 \\
\hline Peru & 8.8 & 7.5 \\
\hline
\end{tabular}

A similar simulation was performed to obtain a target administrative fee and a target contribution rate. When a target administrative fee is obtained, the results for 3 out of 4 countries showed negative values. That is, that the pension fund administrative entities in Costa Rica, Dominican Republic and Mexico would need not to charge any fee at all, in order for the worker to achieve the target replacement rate. On the other hand, Peru showed that if the charge fee on assets under management decreased to $0.08 \%$, the replacement rate of $70 \%$ is reached, keeping the charge on assets under management uncharged. On the contrary, if the fee on assets under management is maintained, a negative fee on flows would need to be charged in order to reach a $70 \%$ replacement rate for this country.

Table 8. Target contribution rate assuming a 70\% replacement rate

\begin{tabular}{|c|c|c|}
\hline Country & $\begin{array}{c}\text { Target contribution } \\
\text { rate (\%) }\end{array}$ & $\begin{array}{c}\text { Current contribution } \\
\text { rate (\%) }\end{array}$ \\
\hline Costa Rica & 16.4 & 4.25 \\
\hline Dominican Republic & 15.5 & 8.0 \\
\hline Mexico & 13.4 & 7.79 \\
\hline Peru & 12.6 & 10 \\
\hline
\end{tabular}

Under the same reasoning, a target contribution rate was also calculated; the results are shown in Table 8 . It can be seen that, a worker needs to increase the contribution rate 12.12 percentage points for the case of Costa Rica, 7.48 in Dominican Republic, 5.63 in Mexico and 2.57 in Peru, in order to obtain a minimum of $70 \%$ of his salary at retirement age. That is, an average worker in Costa Rica needs to contribute to his pension fund 12.12 
percentage points in addition to what he is doing it currently, which means a proportional reduction to his salary. Therefore, Costa Rica is the more dramatic scenario, as the contribution needs to increase almost 3 times from the current value. A similar explanation applies for all other three countries.

\section{Conclusions}

Even when most of Latin American pension systems were created on the basis of the Chilean experience, each one has incorporated particular adequacies, in order to be consistent with their specific national context. For this reason, is natural that each country has its own characteristics, which of course will drive to different results. This matter is of particular interest for the workers, since that the Latin American pension reforms have transferred the risks from the governments to the individuals. That is why is commonly said that Latin American DC schemes are successful from the financial sustainability point of view, but at the cost of involving a high uncertainty for the workers regarding their expected income at retirement.

From this perspective, as of 2012, we observed that 5 out of 8 analyzed countries reached an efficient replacement rate with $70 \%$ minimum. However, as of 2016 only 4 out of 8 analyzed countries are able to achieve adequate retirement rates for their members. This is because of several reasons explained as follows. Costa Rica, Dominican Republic and Mexico are still among the countries that do not provide mechanisms to the workers to obtain adequate replacement rate at retirement. Costa Rica, Dominican Republic and Mexico decreased the target rate of return that is needed to achieve a $70 \%$ replacement rate. Costa Rica mainly because the charge fee on assets under management decreased and the average monthly wage increased in the last 4 years, Dominican Republic because the average rate or return on pension funds and the average monthly wage increased. Mexico decreased the charge fee on assets under management at the same time that the percentage of the contribution increased.

Peru is the only analyzed country that in the last 4 years decreased dramatically the replacement rate. This is because a charge on assets under management was introduced to a $1.21 \%$ value, which is higher than the fee charged in the other countries from the region. Uruguay is the country that even though the percentage of the contribution and the average rate of return decreased, at the same time that the charge on flows increased and the charge fee on assets under management was introduced, the replacement rate is still above $70 \%$.

Dominican Republic and Mexico must improve their average real returns for around 2 percentage points, in order to reach a target of $70 \%$ replacement rate. The challenge is even harder for Costa Rica, where the average real return must improve 5 percentage points and lower for Peru with 1.25 percentage points, in order to get the desired replacement rate of $70 \%$. However, is important to point out that recent research suggest that even when the $70 \%$ replacement rate is generally accepted as a target, it is not necessarily correlated with the household wellbeing.

Obviously, the behavior of the return rates depends on many factor, most of them out of control of the fund managers. That is why, even when asset allocation is a fundamental matter for the proper function of a pension fund, is even more important to pay attention to the design parameters of the plans; as these have more significant impacts on the expected benefits, beside their mandatory nature. In this sense, we determined what should be a proper contribution rate in the countries with the lower expected replacement rates, in order to achieve a target; and we found that in all three countries, they were around the double of their current contributions.

Of course, is not feasible to propose to increase the contribution rates in countries where the available income is rather low. However, if this situation is not corrected at the appropriate time, it will be worse for the workers at retirement ages, when they face an important reduction of their income.

\section{Acknowledgements}

We are very grateful to Edgar Fuantos, Alan Rivera and Jessica Guerra, students from the Bachelor in Economics, for their invaluable help to search for databases to make this project possible; and to the anonymous referees who evaluated this paper, for their appropriate and constructive suggestions to improve this work.

\section{REFERENCES}

[1] FIAP, Informativo FIAP, Marcha de los Sistemas de Pensiones, No.3., 2017.

[2] J. Duarte \& C. Elizalde, La década de los fondos de pensiones en los países latinoamericanos. Revista venezolana de análisis de coyuntura, Vol.7, No.1, 71-90. 2011

[3] R. Ham, Las reformas a la seguridad social. De la solidaridad intergeneracional a la privatización de las pensiones. DemoS, 36-37, 1996

[4] M. Bertranou, Sistemas de jubilaciones y pensiones en América Latina: Reformas, paradigmas y temas emergentes. Prudentia iuris, No. 59, 11-30. 2004.

[5] OECD, Pensions at a glance 2013, OECD and G20 Indicators, OECD Publishing, 2013.

[6] Online available from: http://www.populationpyramid.net

[7] S. Murillo \& F. Venegas, M.F. Cobertura de los sistemas de 
pensiones y factores asociados al acceso a una pensión de jubilación en México. Papeles de población, Vol. 17, No. 67, 209-250. 2011.

[8] D. Blake, Pension finance, New Jersey, John Wiley and Sons, 2006.

[9] P. Booth, R. Chadburn, S. Haberman, D. James, Z. Khorasanee, R. Plumb \& B. Rickayzen, Modern actuarial theory and practice (2nd ed.), United States, Chapman \& Hall, 2005

[10] A. Cairns, D. Blake \& K. Dowd, Stochastic lifestyling: Optimal dynamic asset allocation for defined contribution pension plans, Journal of Economic Dynamics and Control, Vol. 30, No. 5, 843-877, 2006.

[11] OECD, Pensions at a Glance 2015: OECD and G20 Indicators, OECD Publishing, 2015.

[12] Online available from: data.oecd.org/pension/net-pension-replacement-rates.htm

[13] F. Larraín V. El Sistema Privado De Pensiones En Chile Y Sus Resguardos Constitucionales. Revista chilena de derecho, Vol. 39, No. 2, 541-551, 2012.

[14] Banco Interamericano de Desarrollo. Panorama de las Pensiones. América Latina y el Caribe. OCDE, Banco Mundial, BID, 2015.
[15] D. Gomez-Hernandez \& F. Perez-Sosa, Target Rates of Return in Latin American DC Pension Systems, Benefits \& Compensation International, Vol. 44, No. 3, 12-17, 2014.

[16] E. Vigna \& S. Haberman, S. Optimal investment strategy for defined contribution pension scheme. Insurance: Mathematics and Economics, No. 28, 233-262, 2001.

[17] J.K. Scholz \& A. Seshadri. What Replacement Rates Should Households Use? Michigan Retirement Research Center, 2009.

[18] A.H. Munnell \& M. Soto. What Replacement Rates do Households Actually Experience in Retirement? Center for Retirement Research at Boston College, 2005.

[19] B.J. MacDonald L. Osberg \& K.D. Moore. How Accurately Does 70\% Final Employment Earnings Replacement Measure Retirement Income (In)Adequacy? Introducing the Living Standards Replacement Rate (LSRR). Astin Bulletin, Vol. 46, No. 3, 627-676, 2016.

[20] FIAP, Boletín Estadístico AIOS, No.12, 2016.

[21] Online available from: www.fiapinternacional.org/wp-content/uploads/2016/01/Ta sa-de-Cotización_Contribution-Rate-2.xlsx

[22] FIAP, Informe Ejecutivo Estadístico, No.36, 2015.

[23] Institute of Actuaries, Formulae and tables for actuarial examinations, Great Britain, Alden Press Oxford, 1980. 